Hormonal regulation of fatty acid synthesis in adipose tissue through changes in the activities of pyruvate dehydrogenase (EC 1.2.4.1) and acetyl-CoA carboxylase (EC 6.4.1.2)

By R. M. Denton, Department of Biochemistry, University of Bristol, Medical School, University Walk, Bristol BS8 ITD

The rate of fatty acid (FA) synthesis in rat epididymal adipose tissue can be altered very strikingly by hormones both in the short and long term.

Insulin and catabolic hormones (such as adrenaline) have opposing acute effects which can be observed in vitro after only a few minutes exposure to the hormones. These effects cannot be explained solely in terms of changes in glucose uptake or lipolysis: rather it appears that insulin specifically activates the conversion of pyruvate carbon atoms to FA, in addition to its effect on glucose transport, and that this effect is opposed by adrenaline (Denton, Halperin \& Randle, I968; Denton \& Martin, 1970; Halperin, 1970; Jungas, 1970; Coore, Denton, Martin \& Randle, $197 \mathrm{r}$ ). Recent studies indicate that the acute effects of these two hormones are brought about by parallel alterations in the activity of two key enzymes in this pathway segment. One is the mitochondrial enzyme complex, pyruvate dehydrogenase ( $E C$ 1.2.4.I) (Coore et al. 197I; Denton, Coore, Martin \& Randle, 1971; Jungas, 1971; Weiss, Löffler, Schirmann \& Wieland, 1971; Martin, Denton, Pask \& Randle, 1972; Taylor, Mukherjee \& Jungas, 1973; Severson, Denton, Pask \& Randle, 1974); the other is the cytoplasmic enzyme acetyl-CoA carboxylase ( $E C$ 6.4.I.2) (Halestrap \& Denton, 1973, 1974a). Both enzymes have interconvertible active and inactive forms. Some aspects of the interconversion are indicated in Fig. $I$ and are briefly reviewed below with an outline of investigations in this laboratory focussed on the intriguing problem of how the interaction of hormones with receptors on the outside of the cell membrane can lead to the observed acute changes in activity of both a cytoplasmic and a mitochondrial enzyme system. We have been further spurred by the possibility that such studies appeared to offer a possible means of understanding more about the mechanism of action of insulin in general. At present there is no satisfactory explanation of the hormone's actions on a number of other intracellular processes including glycogen synthesis and lipolysis.

Long-term regulation of FA synthesis in adipose tissue following alterations of the nutritional or hormonal status of rats has been well documented and in many instances has been shown to be associated with marked induction or repression of many of the enzymes involved in the pathway of FA synthesis, including acetyl$\mathrm{CoA}$ carboxylase (e.g. Saggerson \& Greenbaum, 1970). Effects of diabetes, starvation and fat feeding on the activity of pyruvate dehydrogenase are also 


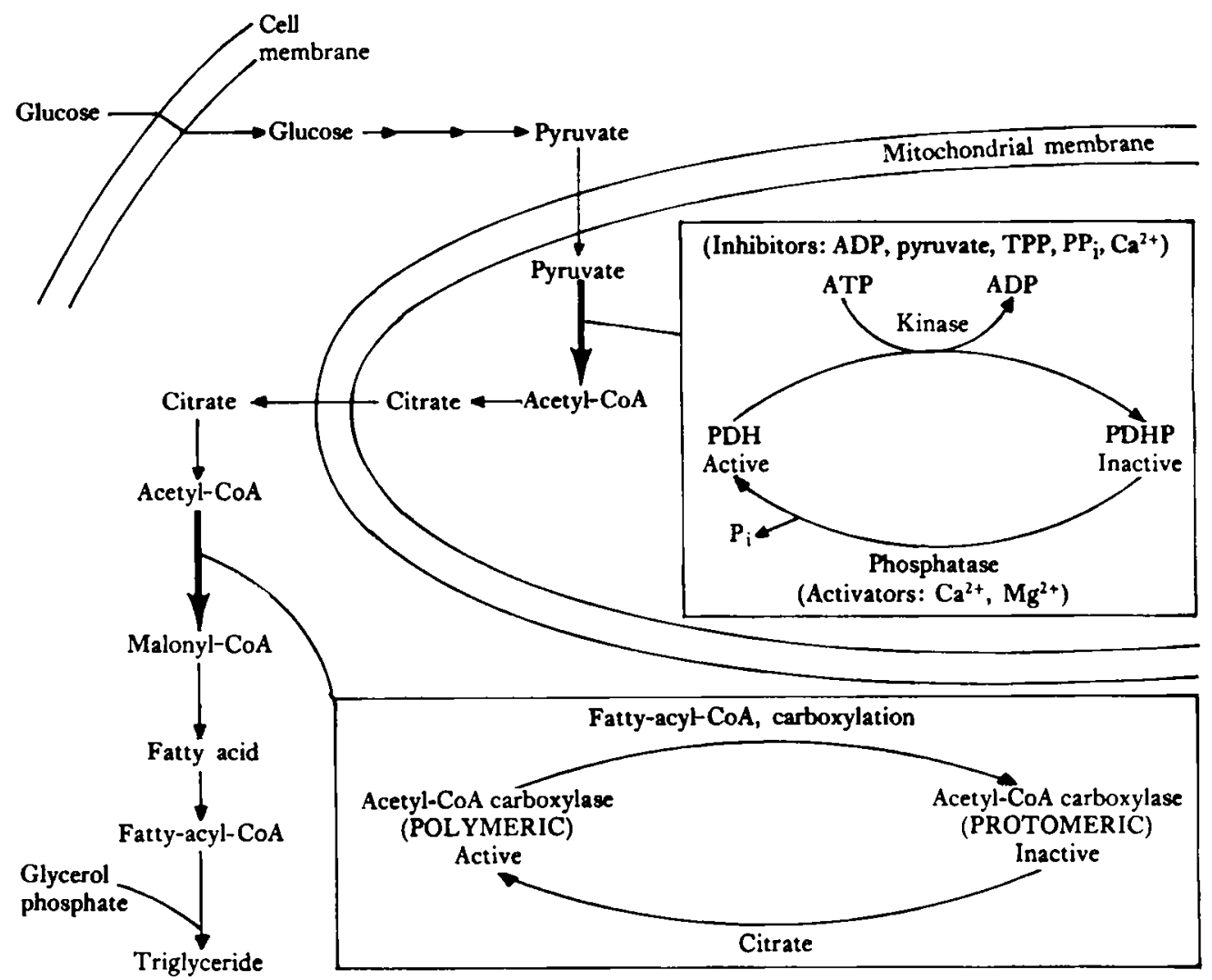

Fig. I. Outline of the pathway of fatty acid synthesis from glucose in adipose tissue with some details of the regulation of pyruvate dehydrogenase (PDH) (EC 1.2.4.1) and acetyl-CoA carboxylase (EC 6.4.1.2) activity. TPP, thiamin pyrophosphate; $\mathrm{PP}_{\mathrm{i}}$, inorganic pyrophosphate; $\mathrm{PDHP}$, phosphorylated pyruvate dehydrogenase; $\mathrm{P}_{\mathfrak{i}}$, inorganic phosphate.

reviewed below. These conditions all lead to a marked diminution in fat synthesis and to repression of acetyl-CoA carboxylase activity.

\section{Regulation of acetyl-CoA carboxylase}

Acetyl-CoA carboxylase from mammalian sources probably contains three nonidentical subunits: a biotin-binding protein, biotin carboxylase and a transcarboxylase. The subunits form protomers (molecular weight about $4 \times 10^{5}$ ) but the enzyme is only active when the protomers combine into long, filamentous polymers (molecular weight $\left.4 \times 10^{6}-8 \times 10^{6}\right)$. Aggregation is favoured by citrate, whereas fatty-acyl-CoA (FA-CoA) or carboxylation of the enzyme by ATP- $\mathrm{Mg}^{2+}$ in the presence of $\mathrm{HCO}_{3}^{-}$cause disaggregation (for reviews see Lane \& Moss, I971; Volpe \& Vagelos, 1973). The enzyme seems to be uniquely sensitive to FA-CoA; effects on the pigeon liver and rat adipose tissue enzymes are seen at concentrations below I $\mu \mathrm{M}$ and are reversible (Goodridge, 1972; Halestrap \& Denton, 1973, 1974a). 
Halestrap \& Denton (1974a) showed that the activity of acetyl-CoA carboxylase was increased twofold in extracts from insulin-treated adipose tissue provided that the tissue was incubated in the presence of glucose or fructose and that assays were performed immediately after extraction (Fig. 2). Insulin appeared to have little or no effect on the total activity of the enzyme, since preincubation of extracts with citrate before assay led to activation of the enzyme and loss of the effect of insulin. Adrenaline in the presence of glucose and insulin decreased the initial activity of the enzyme in tissue extracts but had no effect on the total activity. A large decrease in initial activity was also seen after a short period of starvation ( 36 h) although the total activity was only slightly reduced by this treatment. These findings suggested that the changes in initial activity observed reflected changes in the ratio of polymeric to protomeric forms of the enzyme in the intact tissue. To confirm this a method using high-speed centrifugation was devised which allowed substantial separation of the two forms. Extracts from insulin-treated fat pads contained a greater fraction of the enzyme in its polymeric form, whereas prior exposure of fat pads to adrenaline in the presence of insulin increased the proportion of the enzyme in its inactive protomeric form (Halestrap \& Denton, $1973,1974 a$ ).
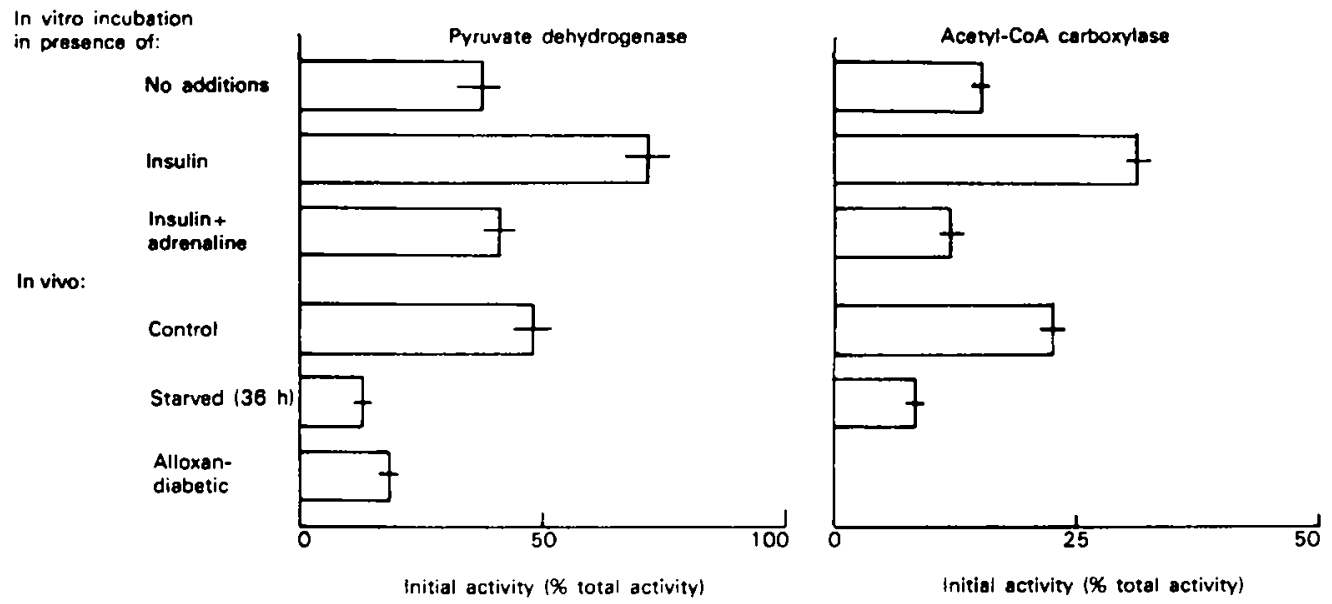

Fig. 2. Changes in the initial activity of pyruvate dehydrogenase $(E C$ 1.2.4.1) and acetyl-CoA carboxylase (EC 6.4.1.2) in rat epididymal adipose tissue in the presence of insulin or adrenaline, or after starvation or alloxan-diabetes. Results for pyruvate dehydrogenase initial activity are taken from Severson, Denton, Pask \& Randle (1974), Stansbie, Denton \& Randle (r975) and Denton (unpublished results) and are expressed as a percentage of total activity (observed after incubation of the tissue extract with pyruvate dehydrogenase phosphate phosphatase in the presence of $\mathbf{M g}^{2+}$ and $\mathrm{Ca}^{2+}$ ). Results for acetyl-CoA carboxylase initial activity are taken from Halestrap \& Denton (1974a) and are expressed as a percentage of total activity (observed after incubation of the tissue extract with citrate). Horizontal bars indicate standard errors (four to eight observations).

It has been suggested that a phosphorylation-dephosphorylation cycle may be involved in the regulation of the liver acetyl-CoA carboxylase (Carlson \& Kim, $1974 a, b)$. However, we have been unable to obtain any convincing evidence that the changes observed in adipose tissue are associated with such a cycle; rather it 
seems more likely that the changes observed are the result of either changes in citrate or FA-CoA. Although we cannot completely eliminate the possibility that citrate may regulate the enzyme, because of compartmentation of the metabolite between mitochondria and cytoplasm, we have taken the complete lack of correlation between tissue concentrations of citrate and the initial activity of acetyl-CoA carboxylase to imply that regulation by citrate may not be of physiological importance under the conditions studied. Most strikingly, in tissues incubated with pyruvate an eightfold rise in citrate was seen when there was no significant change in the initial activity of acetyl-CoA carboxylase. On the other hand, there is evidence of an inverse correlation between whole tissue FA-CoA levels and the initial activity seen with insulin. However, the lowering in initial activity seen with adrenaline or in tissues from starved animals was not associated with a clear increase in tissue FA-CoA concentration (Halestrap \& Denton, 1974a).

\section{Regulation of the pyruvate dehydrogenase complex}

Three separate enzymes are involved in the conversion of pyruvate into acetylCoA: pyruvate decarboxylase ( $E C$ 4.I.I.I), dihydrolipoate acetyltransferase (lipoate acetyltransferase; $E C$ 2.3.1.12) and dihydrolipoate dehydrogenase (lipoamide dehydrogenase; $E C$ 1.6.4.3). The activity of the complex may be regulated by two types of control: end-product inhibition by high ratios of acetylCoA:CoA and NADH:NAD, which may involve accumulation of acetylhydrolipoate (Garland \& Randle, 1964; Randle, Garland, Hales, Newsholme, Denton \& Pogson, 1966), and interconversion of phosphorylated (inactive) and dephosphorylated (active) forms (Linn, Pettit, Hucho \& Reed, 1969; Linn, Pettit \& Reed, 1969). Inactivation is catalysed by an ATP-requiring kinase which is strongly bound to the complex; pyruvate dehydrogenase phosphate phosphatase is loosely associated with the complex and reactivates the enzyme by removing the covalently bound phosphate (for reviews see Reed, r 974; Denton, Randle, Bridges, Cooper, Pask, Severson, Stansbie \& Whitehouse, 1975).

The doubling in pyruvate dehydrogenase activity in extracts of adipose tissue previously exposed to insulin for 10-30 min appears to be the result of an increase in the proportion of the complex in the active form (Fig. 1 ). The effect of insulin is lost if the extracts are treated with pyruvate dehydrogenase phosphate phosphatase under conditions which allow conversion of all the complex in the inactive form into the active, non-phosphorylated form (Coore et al. 1971; Weiss et al. 1971; Severson et al. 1974). Thus the effects of insulin could be brought about either by an activation of the phosphatase or by inhibition of the kinase or both. The kinase from a number of sources has been found to be inhibited by ADP and pyruvate (Hucho, Randall, Roch, Burgett, Pelley \& Reed, 1972; Cooper, Randle \& Denton, 1974) and this appears to be the situation for the adipose tissue enzyme (Martin et al. 1972). More recent studies with the pig heart enzyme have shown that the regulation of the kinase is complex and that thiamin pyrophosphate, $\mathrm{Ca}^{2+}$ and high concentrations of $\mathrm{Mg}^{2+}$ may also inhibit and that acetoin may activate (Cooper et al. 1974) but it is not known to what extent this applies to the adipose tissue enzyme. The phosphatase, including that from 
adipose tissue, not only requires $\mathrm{Mg}^{2+}$ but also is markedly activated by low ( $\left.\mu \mathrm{M}\right)$ concentrations of $\mathrm{Ca}^{2+}$ (Linn, Pettit, Hucho \& Reed, 1969; Linn, Pettit \& Reed, 1969; Denton, Randle \& Martin, 1972; Randle, Denton, Pask \& Severson, 1974; Severson et al. 1974). No effects of cyclic AMP have been found on any component of the pyruvate dehydrogenase complex or on pyruvate dehydrogenase activity in intact mitochondria (Coore et al. 1971; Martin et al. 1972).

The effect of insulin persists during preparation of mitochondria from fat cells or fat pads and is still evident after 10-20 min incubation of fat-pad mitochondria with oxoglutarate and malate in the absence of pyruvate (Fig. 3). Under these circumstances there can be little or no pyruvate in the mitochondria and ATP concentration in mitochondria from both insulin-treated and control tissues is the same. This would appear to rule out changes in pyruvate or adenine nucleotides as being important in the effect of insulin.

One possible explanation of the persistence of the insulin effect during isolation and incubation of fat-pad mitochondria is that insulin alters the mitochondrial content of an effector of the pyruvate dehydrogenase system which is not metabolized or lost from the mitochondria; $\mathrm{Ca}^{2+}$ is such an effector. Further indirect evidence that $\mathrm{Ca}^{2+}$ may be involved in the action of insulin has been the finding that the effect of insulin is inhibited by Ruthenium Red, $\mathrm{NiCl}_{2}$ and $\mathrm{MnCl}_{2}$, which are inhibitors of mitochondrial or cellular uptake of $\mathrm{Ca}^{2+}$ (Severson et al. 1974) and that ouabain mimics the effect of insulin (Martin et al. 1972). More
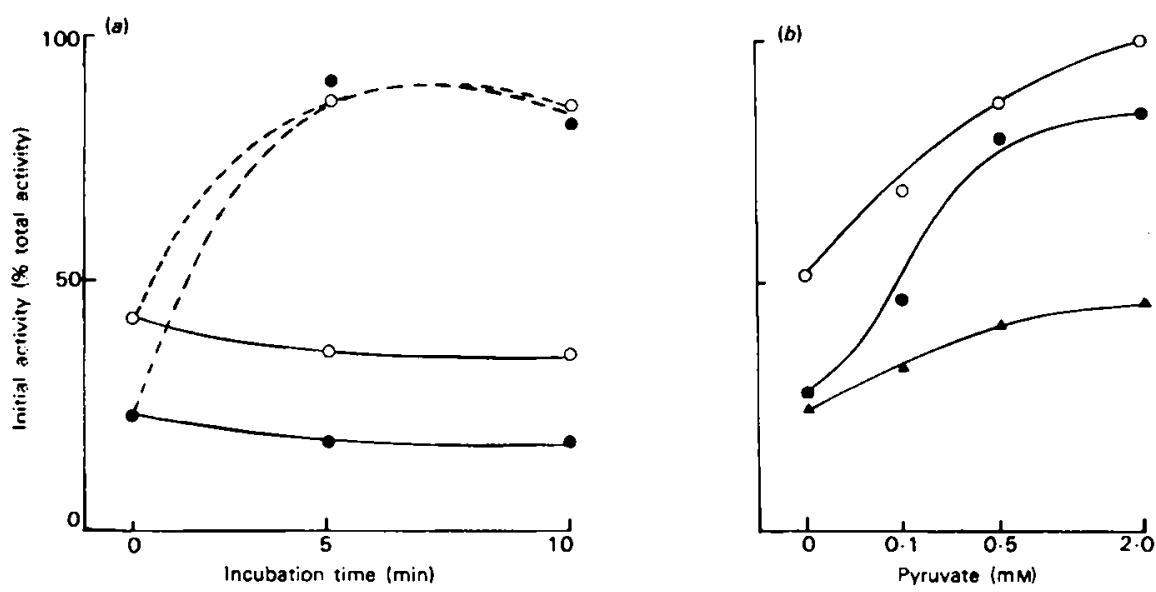

Fig. 3. Pyruvate dehydrogenase ( $E C$ 1.2.4.I) activity in mitochondria from fat pads of normal and alloxan-diabetic rats previously incubated in the presence or absence of insulin? incubations of fat pads were for $30 \mathrm{~min}$ and then mitochondria were rapidly prepared. (a) Mitochondria from fat pads of normal rats previously incubated in the absence $(O)$ or presence $(O)$ of insulin were incubated at $30^{\circ}$ for various periods of time in medium with $(-O)$ or without (O--.-O, 0 - - O) added oxoglutarate and malate; $(b)$ mitochondria from fat pads of normal rats previously incubated in the presence of insulin (O) and from fat pads of normal $(\boldsymbol{O})$ and alloxan-diabetic (A) rats previously incubated in the absence of insulin were incubated at $30^{\circ}$ for $4 \mathrm{~min}$ in medium with oxoglutarate, malate and various concentrations of pyruvate. After centrifugation for $15 \mathrm{~s}$, mitochondrial pellets were extracted and assayed for initial and total pyruvate dehydrogenase activity. Results are mean values for two to four mitochondrial preparations (R. M. Denton, B. J. Bridges, D. L. Severson \& P. J. Randle, unpublished results). 
direct evidence was sought by incubating fat pads and fat cells with ${ }^{45} \mathrm{Ca}$ and studying the incorporation of ${ }^{45} \mathrm{Ca}$ into mitochondrial fractions rapidly prepared in sucrose medium containing both Ruthenium Red and ethylene glycol tetra-acetic acid (EGTA) to stop redistribution of ${ }^{45} \mathrm{Ca}$ during preparation of the fractions. Incorporation of ${ }^{45} \mathrm{Ca}$ into mitochondria of fat cells was much greater than the incorporation into those of intact fat pads, and was found to be complete within a few minutes. However, no convincing evidence of an effect of insulin on the rate or extent of ${ }^{45} \mathrm{Ca}$ incorporation has been obtained. Moreover, incubation of fat pads with calcium-free medium containing EGTA after a period of preincubation in medium containing ${ }^{45} \mathrm{Ca}$ results in a marked reduction in ${ }^{45} \mathrm{Ca}$ content of the mitochondrial fraction without any change in pyruvate dehydrogenase activity (Severson, Denton, Bridges \& Randle, 1976). On present evidence, one must conclude that although the phosphatase is undoubtedly sensitive to $\mathrm{Ca}^{2+}$ in fat cell mitochondria (Severson et al. 1974), the concentration of $\mathrm{Ca}^{2+}$ normally present saturates the enzyme and thus changes in mitochondrial $\mathrm{Ca}^{2+}$ may not be important in the hormonal regulation of pyruvate dehydrogenase in adipose tissue.

Adrenaline reverses the action of insulin (Coore et al. 1971; Fig. 1). The proportion of pyruvate dehydrogenase in the active form is also markedly lower in fat pads of starved $(36 \mathrm{~h}$ ) or alloxan-diabetic animals (Stansbie, Denton \& Randle, 1975). This diminution still persists after incubation with insulin for $60 \mathrm{~min}$, which suggests that there is a long-term alteration in the metabolism of tissues from starved or alloxan-diabetic rats which is not corrected during incubation with insulin. This alteration appears to effect the interconversion of the two forms of the pyruvate dehydrogenase complex by a mechanism largely independent of that involved in the activation by insulin. Studies on isolated mitochondria support this view. Addition of pyruvate (an inhibitor of pyruvate dehydrogenase kinase) to mitochondria causes a marked increase in the proportion of the enzyme in the active form if the mitochondria are prepared from fat pads of normal animals but not if they come from fat pads of alloxan-diabetic animals (Fig. 3). Similar differences in sensitivity to pyruvate have been observed previously in heart mitochondria from normal and alloxan-diabetic rats (A. L. Kerbey \& P. J. Randle, unpublished results).

Giving rats a balanced diet containing approximately $400 \mathrm{~g} \mathrm{fat} / \mathrm{kg}$ also results in a marked reduction in the initial activity of pyruvate dehydrogenase. After $6 \mathrm{~d}$ on the diet the reduction can be largely accounted for as a change in the proportion of the enzyme in its active form; but after $22 \mathrm{~d}$ a marked reduction in the total pyruvate dehydrogenase activity becomes evident and the proportion of the enzyme in the active form is not appreciably different from controls (Stansbie et al. 1975).

\section{Some thoughts on the role of $F A-C o A$ in the regulation of $F A$ synthesis}

Studies on acetyl-CoA carboxylase suggest that acute regulation of this enzyme may be through changes in the cytoplasmic concentration of FA-CoA. However, the concentration of FA-CoA in fat cells calculated on the basis of the metabolite 
being evenly distributed throughout the cell is two or three orders of magnitude greater than the apparent $K_{i}$ of acetyl-CoA carboxylase for palmitoyl-CoA and indeed the concentration would be such as to irreversibly denature most enzymes. It would appear that extensive binding of FA-CoA must occur within the cell and this is in accord with the coexistence of FA-CoA with high activities of FA-CoA hydrolyase within cells. If FA-CoA were very largely bound to specific proteins within cells then it could be envisaged that the binding may be regulated allowing the concentration of free FA-CoA to vary independently of the whole tissue concentration. The low-molecular-weight, FA-binding or ' $Z$ ' protein described by Ochner, Manning, Poppenhauser \& Ho (1972), Mishkin, Stein, Gatmaitan \& Arias (1972) and Mishkin \& Turcotte (1974) would seem a very likely candidate. This protein binds both FA-CoA and FA; thus free intracellular concentrations of FA-CoA may be increased under conditions of enhanced lipolysis without there being an increase in the whole tissue concentration if FA displaced FA-CoA from the protein. This is a possible mechanism for the lack of inverse correlation between whole tissue concentrations of FA-CoA and the initial activity of acetyl$\mathrm{CoA}$ carboxylase seen after starvation and on incubation of pads with adrenaline (Halestrap \& Denton, 1974a). It also offers a plausible mechanism for the increases in rates of esterification which occur under these conditions.

The parallel changes (Fig. 2) in activity of pyruvate dehydrogenase with those of acetyl-CoA carboxylase suggests that mechanisms involved in the acute hormonal regulation of these enzymes may be closely linked. For example, changes in cytoplasmic concentration of FA-CoA might initiate changes in the activity of both enzymes if cytoplasmic levels of FA-CoA can regulate the concentration of an effector of the pyruvate dehydrogenase system. FA-CoA may be a physiological inhibitor of the mitochondrial transport of adenine nucleotides (Pande \& Blanchaer, 1971; Vaartjes, Kemp, Souverijn \& van der Bergh, 1971; Lerner, Shug, Elson \& Shrago, 1972), and it has been argued that a decrease in the cytoplasmic concentration of FA-CoA may lead in turn to a decrease in the mitochondrial ATP:ADP ratio and activation of pyruvate dehydrogenase (Taylor \& Jungas, r 974; Weiss, Löffler \& Wieland, 1974). Alternatively, as mitochondria contain a specific transporter for pyruvate (Halestrap \& Denton, 1974b; Halestrap, 1975), it could be envisaged that changes in the activity of this transporter may lead to alterations in the activity of pyruvate dehydrogenase. However, the persistence of the effect of insulin during isolation and subsequent incubation of mitochondria from fat pads (Fig. 2a) would appear to make these possibilities rather unlikely explanations of the mechanism of action of insulin.

The effects of alloxan-diabetes and probably also starvation on the activity of pyruvate dehydrogenase appear to be brought about by mechanisms largely independent of those involved with the effects of insulin. The underlying cause of the loss of sensitivity to pyruvate observed in fat-pad mitochondria from alloxandiabetic rats has not been established but it could reflect alterations in pyruvate uptake or in sensitivity of the kinase to pyruvate. Although it would appear likely that this phenomenon is associated with increased rates of lipolysis, a precise role for FA-CoA has not been defined. 
The pyruvate dehydrogenase system in isolated fat-pad mitochondria can 'remember' whether the mitochondria have been prepared from control fat pads, or pads previously exposed to insulin, or pads from alloxan-diabetic rats. It is hoped that future studies aimed at understanding the basis of this 'memory' will permit the mechanisms involved in the hormonal regulation of adipose tissue pyruvate dehydrogenase and therefore of FA synthesis in that tissue to be established.

The studies described above have been in close collaboration with Professor P. J. Randle and a large number of other colleagues mentioned in the text and relevant references and have been supported by grants from the Medical Research Council and the British Diabetic Association.

\section{REFERENCES}

Carlson, C. A. \& Kim, K. (1974a). Archs Biochem. Biophys. $164,478$.

Carlson, C. A. \& Kim, K. (1974b). Archs Biochem. Biophys. 164, 490.

Cooper, R., Randle, P. J. \& Denton, R. M. (1974). Biochem. Y. 143, 625.

Coore, H. G., Denton, R. M., Martin, B. R. \& Randle, P. J. (1971). Biochem. F. 128, 161.

Denton, R. M., Coore, H. G., Martin, B. R. \& Randle, P. J. (I971). Nature New Biol. 231, I 5.

Denton, R. M., Halperin, M. L. \& Randle, P. J. (1968). In Physiopathology of Adipose Tissue, p. 3I [J. Vague and R. M. Denton, editors]. Amsterdam: Excerpta Medica Foundation.

Denton, R. M. \& Martin, B. R. (1970). In Adipose Tissue: Regulation and Metabolic Functions, p. I 43 [B. Jeanrenaud and D. Hepp, editors]. London: Academic Press.

Denton, R. M., Randle, P. J., Bridges, B. J., Cooper, R., Pask, H. T., Severson, D. L., Stansbie, D. \& Whitehouse, S. (1975). Mol. cell. Biochem. (In the Press.)

Denton, R. M., Randle, P. J. \& Martin, B. R. (1972). Biochem. F. 128, 161.

Garland, P. B. \& Randle, P. J. (1964). Biochem. F. 9I, 6c.

Goodridge, A. G. (1972). F. biol. Chem. 247, 6946 .

Halestrap, A. P. (1975). Biochem. F. 148, 85.

Halestrap, A. P. \& Denton, R. M. (1973). Biochem. F. 132, 509.

Halestrap, A. P. \& Denton, R. M. (1974a). Biochem. F. 142, 365.

Halestrap, A. P. \& Denton, R. M. (1974b). Biochem. Ұ. $\mathbf{1 3}^{8}, 3^{13}$.

Halperin, M. L. (1970). Can. F. Biochem. 48, 1228.

Hucho, F., Randall, D. D., Roch, T. E., Burgett, M. W., Pelley, J. W. \& Reed, L. J. (1972). Archs Biochem. Biophys. I51, 328.

Jungas, R. L. (1970). Endocrinology 86, 1368.

Jungas, R. L. (1971). Metabolism 20, 43.

Lane, M. D. \& Moss, J. (1971). Metab. Pathrways 5, 23.

Lerner, E., Shug, A. L., Elson, C. \& Shrago, E. (1972). \%. biol. Chem. 247, 1513.

Linn, T. C., Pettit, F. H., Hucho, F. \& Reed, L. J. (1969). Proc. natn. Acad. Sci. U.S.A. 64, 227.

Linn, T. C., Pettit, F. H. \& Reed, L. J. (1969). Proc. natn. Acad. Sci. U.S.A. 62, 234.

Martin, B. R., Denton, R. M., Pask, H. T. \& Randle, P. J. (1972). Biochem. f. 129, 763.

Mishkin, S., Stein, L., Gatmaitan, Z. \& Arias, I. M. (1972). Biochem. biophys. Res. Common. 47, 997.

Mishkin, S. \& Turcotte, R. (1974). Biochem. biophys. Res. Commun. 57, 918.

Ochner, R. K., Manning, J. A., Poppenhauser, R. B. \& Ho, W. K. L. (1972). Science, N.Y. 177, 56.

Pande, S. V. \& Blanchaer, M. C. (1971). J. biol. Chem. 246, 402.

Randle, P. J., Denton, R. M., Pask, H. T. \& Severson, D. L. (I974). Biochem. Soc. Symp. 39, 75.

Randle, P. J., Garland, P. B., Hales, C. N., Newsholme, E. A., Denton, R. M. \& Pogson, C. I. (1966). Recent Prog. Horm. Res. 22, 1.

Reed, L. J. (1974). Accts chem. Res. 7, 40.

Saggerson, E. D. \& Greenbaum, A. L. (1970). Biochem. F. 119, 221.

Severson, D. L., Denton, R. M., Bridges, B. J. \& Randle, P. J. (1976). Biochem. F. (In the Press.)

Severson, D. L., Denton, R. M., Pask, H. T. \& Randle, P. J. (1974). Biochem. F. 140, 225.

Stansbic, D. L., Denton, R. M. \& Randle, P. J. (1975). Biochem. Soc. Trans. (In the Press.)

Taylor, S. I. \& Jungas, R. L. (I974). Archs Biochem. Biophys. 164, 12.

Taylor, S. I., Mukherjee, C. \& Jungas, R. L. (1973). F. biol. Chem. 248, 73.

Vaartjes, W. J., Kemp, A., Souverijn, J. H. M. \& van der Bergh, S. G. (1971). FEBS Lett. $23,303$.

Volpe, J. J. \& Vagelos, P. R. (1973). A. Rev. Biochem. 42, 2 I.

Weiss, L., Löffler, G., Schirmann, A. \& Wieland, O. (1971). FEBS Lett. 15, 229.

Weiss, L., Löffler, G. \& Wieland, O. (1974). Hoppe-Seyler's Z. physiol. Chem. 355, 363.

\section{Printed in Great Britain}

